\title{
PLANT LANDSCAPE AND MODELS OF FRENCH ATLANTIC ESTUARINE SYSTEMS. EXTENDED SUMMARY OF THE DOCTORAL THESIS
}

Kevin CIANFAGLIONE *

* UMR UL/AgroParisTech/INRAE 1434 Silva, Université de Lorraine, Faculté des Sciences et Techniques - BP 70239 - 54506 Vandoeuvre-lès-Nancy, France, kevin.cianfaglione@gmail.com, ORCID: 0000-0001-9915-2503.

DOI: 10.2478/trser-2021-0002

KEYWORDS: Atlantic estuaries, ecological gradients, models, natural and seminatural habitats, (syn)phytology, plant landscape.

\section{ABSTRACT}

The present study proposes a theoretical common model of environmental gradients and functioning of vegetation and Plant Landscape of the French Atlantic estuarine systems. This model offers a basis to improve classification and ecological studies of estuarine systems, and to helps the monitoring and assessment of land uses, land forms transformation and human impacts, thanks to the develop of a spatio-temporal predictive model based on actual and potential vegetation following a dynamico-catenal approach. In eight selected estuaries, fieldworks was undertook for a total of 98,315 ha highlighting two vegetation series and four geopermaseries, corresponding to 131 plant associations, 60 alliances, 43 orders, and 28 classes. The vegetation of three representative estuaries was mapped, for a total of 74,433 ha. A synthetic scheme of estuary vegetation landscape is proposed, integrating geographical and ecological gradients as well as geomorphologic forms.

RÉSUMÉ: Paysage végétal et modèles des systèmes estuariens atlantiques français. Résumé détaillé de la thèse de doctorat.

Cette étude réalise un modèle commun de fonctionnement et de gradients de la végétation et du paysage végétal des systèmes estuariens atlantiques français, afin de constituer une base pour améliorer leur classification et leurs études écologiques, et pour aider au suivi et à l'évaluation des utilisations des terres, de la transformation des formes de terrain et des impacts humains - en développant un modèle prédictif spatio-temporel basé sur la végétation réelle et potentielle en utilisant l'approche dynamico-caténale. Dans huit estuaires sélectionnés, des travaux de terrain ont été entrepris pour un total de 98.315 ha mettant en évidence deux séries de végétation et quatre géopermaseries, correspondant à 131 associations de plantes, 60 alliances, 43 ordres et 28 classes. La végétation de trois estuaires représentatifs a été cartographié pour un total de 74.433 ha. Un schéma du paysage végétal des estuaires est proposé, intégrant les gradients géographiques et écologiques ainsi que les formes géomorphologiques.

REZUMAT: Peisajul vegetal și modelele sistemelor de estuare din Atlanticul francez. Rezumatul extins al tezei de doctorat.

Acest studiu realizează un model teoretic comun al gradienților de mediu și de funcționare a vegetației și a peisajului vegetal al sistemelor de estuare din Atlanticul francez pentru a crea o bază pentru îmbunătățirea clasificării și a studiilor ecologice și pentru a ajuta la monitorizarea și evaluarea utilizărilor terenurilor, transformarea formelor de teren și impactul uman - dezvoltarea unui model predictiv spațio-temporal bazat pe vegetația reală și potențială utilizând abordarea dinamico-catenală. În opt estuare selectate, am întreprins lucrări de teren pentru 9.8315 ha, evidențiind două serii de vegetație și patru geopermaserii, care corespund la 131 asociații de plante, 60 alianțe, 43 de ordine și 28 de clase. Am cartografiat vegetația a trei estuare reprezentative pentru 74.433 ha. Este propusă o schemă sintetică a peisajului de vegetație de estuar, care integrează gradienți geografici și ecologici, precum și fome geomorfologice. 


\section{INTRODUCTION}

\section{Background}

This text derives from and it represents an extended summary of the author $\mathrm{PhD}$ thesis, entitled "Plant landscape and models of French Atlantic estuarine systems" (Cianfaglione, 2018). It was funded by the French Ministry for Environment, as part of the national mapping program of natural and semi-natural habitats (CarHAB Project, convention number 2100992970) and it was conducted following a jointly supervised co-tutorship of PhD program between the University of Camerino (Italy) and the University of Western Brittany (France). The University of Camerino co-financed the place and the $\mathrm{PhD}$ course through a ministerial competition won by the candidate with a public competition. The $\mathrm{PhD}$ thesis was defended in December 2018, in Brest (France) under the Eurolabel (Doctor Europaeus) conditions, an additional certification to $\mathrm{PhD}$ title for having respected the conditions of the Confederation of Conferences of Rectors of EU countries, implemented by the European University Association (EUA). This PhD thesis was evaluated in the research activity carried out for the deliverance of the Young Researcher Award with participation grant at the "7th Aquatic Biodiversity International Conference" Sibiu, Romania (September 25th to 28th, 2019).

In papers that rely on secondary research, the definitions, concepts, principles and methodology sections would provide the necessary background or history for understanding the discussion to come. An overwiew of the available literature more specifically synthesizes information from a variety of significant sources related to the major point of this paper.

\section{Introduction to the research}

All European big river basins including their direct contact areas with seas and oceans are lately under a constant habitats and biodiversity change (Bănăduc et al., 2020; Tockner et al., 2021) reason for which needs permanent high scientific research focus and efforts, based on special on site adapted/designated research methods. Europe has a long-documented tradition in vegetation science and cartography, particularly following the establishment of Josias Braun-Blanquet's International Mediterranean and Alpine Geobotany Station (SIGMA) in the early 20th century (van Der Maarel, 1975; Pignatti, 1995; Pirola, 1999; Cristea et al., 2016; Géhu, 2004, 2006; Ubaldi, 2012) a research center founded by De Leeuw W. C. and Combes R. initiative, and diriged by Braun-Blanquet from its foundation in 1930, until its disappearance in 1980 (Géhu, 2010a, b; 2011). Meanwhile, the 1992 European Habitat-Fauna and Flora Directive has drawn attention to habitats of community interest, which require the development of knowledge in the areas of habitat distribution and mapping (Clergeau and Blanc, 2013). As part of the 2011-2020 National Biodiversity Strategy, the French Ministry of the Environment launched in 2011 a national terrestrial habitat mapping program entitled "National Mapping of Natural and Semi Natural Terrestrial Habitats" (CarHAB), in collaboration with various French institutional and academic structures $(*)$, consequently the CarHAB project was established to produce a 1:25 000 vegetation map of France, following the approaches and concepts of phytosociology and landscape phytosociology (Dynamicocatenal Plant Sociology).

Estuaries have been selected as study areas of the CarHAB program to better understand their originality in terms of flora and dynamic trajectories of vegetation, linked to the landscape, $\beta$-biodiversity, use of land and water.

Estuaries represent a very important system for human uses (Borja et al., 2012; Day et al., 2012; Thrush et al., 2013), and they are very important for their biodiversity issues. Estuaries are commonly considered very rich in nutrients (Middelburg and Herman, 2007) and consequently rich in species, very productive in biomass and as important sources of 
ecosystem services (Muchiut et al., 2008). Generally, these environments are considered of very high importance also following "Birds" and "Habitats" EU directives together within the "Ramsar Convention". National and local administrations improved these directives and conventions by laws, regulations, restrictions, prohibitions and actions - following the different national or local realities, peculiarities and risks. In general, estuarine environments are characterized by high water dynamics and sometimes even violent tides, with frequent variation of the salinity fronts that depend on the daily, seasonal, occasional cycles and extreme events of tides, and on the aquifers dynamics from the catchment areas carried out by rivers (Romaña, 1994).

Estuaries may have undergone very important changes over the centuries due to human pressure (Kestner, 1966; Kragtwijk et al., 2004; Verger, 2005; van Proosdij et al., 2009; Sawtschuk and Bioret., 2012; Di Pietro et al., 2017; Le Dez et al., 2017a, b).

These changes may have created a set of semi-natural and artificial ecosystems in detriment of natural ecosystems, and they may have limited or compromised the primitive functionality of estuary systems and services, changing the physical and chemical quality of the water, tampering the hydraulic functioning, the species composition, the geomorphology and the landscape forms. For that reason, estuaries generally represent a complex of natural and semi-natural habitats, developing from oceans (or seas) to fresh water (bottom-up gradient), and from the lowest to highest water levels, including exceptional flood level where the alluvial plain can be flooded during extreme events (minor-major bed gradient) (**).

A river mouth is the part (the point) of a river or an estuary, that flows into a water body (e.g.: another river, a lake, reservoir, sea, or ocean). At the river mouth the water characteristic changes in some way. The main changes are on water flow conditions, causing changes in currents and related physical, chemical and biological characteristics, together with the erosion and sediment deposition dynamic. In common language, the "river mouth" word can be generically used to denote any geomorphologic type of estuary i.e.: "Bouches du Rhône" - where the Rhone River final portion is anastomized (multiple channel) delta type; and "Embouchures de la Loire" - where the Loire River final portion is from a single channel type.

An estuary corresponds to the river portion where the effect of the sea (or ocean) in which it flows is noticeable (Fig. 1). It concerns the entire portion of the river where the water is salty, brackish and freshwatery. Ocean and sea are here used as synonyms.

In 1967 Pritchard D. W., considered great specialist in estuaries (Romaña, 1994) proposed a definition of them based on scientific considerations: an estuary is a confined body of water with a free connection to the open sea and which seawater is measurably diluted with fresh waters drained in the watershed. It is interesting to note that the word "tide" was not mentioned because some estuaries are not under the influence of tide cycles. Tides determine the tidal estuaries, being the main dynamic factor of the estuarine cycles and related variations. For that, tidal estuaries are more variable in time and space systems. Estuaries body of water are in any case transversally confined in the estuarine bed and longitudinally confined in the area of where the upriver waters are influenced by the sea waters (Fig. 2). Tidal estuaries are in general characterized by: longer surfaces, following the highest tide level, and because in the upper side the freshwater front is influenced by the seawaters following the tide level. This estuarine freshwater portion is also commonly known "dynamical tide portion", while the other downstream portion is commonly known as "salty tide portion" (Guo et al., 2015; Perales-Valdivia et al., 2018). 
The estuarine system could be subdivided in salinity portions following the average water salinity concentration - following the international thalassic series of the "World Ocean Atlas, 2009”, from the downstream to upstream portions (Fig. 3).

Salty water domain:

- Euhaline (mixoeuhaline) zone - more than 30 psu;

- Polyhaline zone - between 30 and 18 psu.

Brackish water domain:

- Mesohaline zone - between 18 and 5 psu;

- Oligohaline zone - between 5 and 0.5 psu.

Freshwater domain:

- under 0.5 psu.

Psu is Practical Salinity Unit, based on water conductivity (salinity); equivalent of grams of salt $(\mathrm{NaCl})$ per $\mathrm{kg}$ of water $(\mathrm{g} / \mathrm{kg})$; or salt grams per liter of water $(\mathrm{g} / \mathrm{l})$. psu could ben be expressed as "ppt (part per thousand)", or using dimensionless numbers, or just followed by the "\%”", or by word "salinity (s)" (Lewis, 1980; Mantyla, 1987).

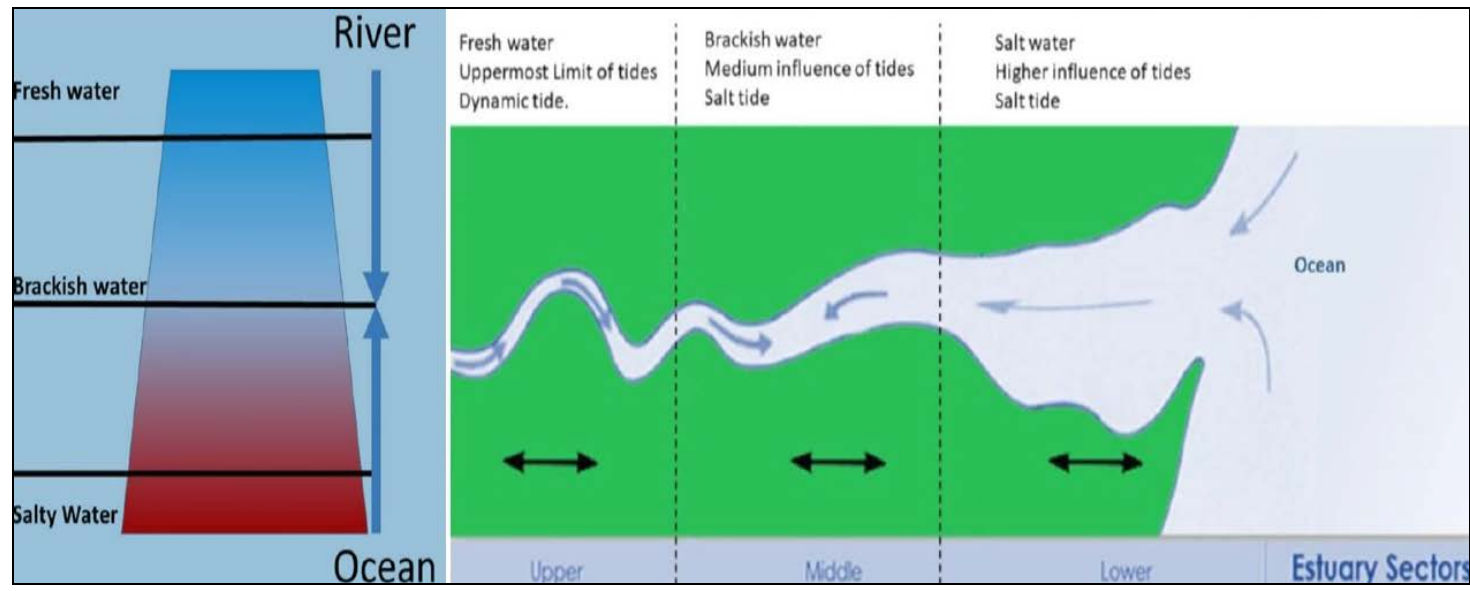

Figure 1: The general salt-freshwater gradient in estuaries

follows the gradient between ocean and river conditions.

By comparison, generally the average ocean salinity is around 35 psu. The limit on agriculture irrigation is normally fixed on 2 psu and the limit for drinking waters commonly is 0.1 psu.

Tides cycles influence salinity zones extension and could shift them along the riverbed. Salty tides are located where the effect of the sea in estuaries is strongest. In the inner estuarine zone, the effect of sea is lesser, only freshwater is present but still under tides influence: the dynamic tides.

Estuarine systems could be classified following the tidal dynamics in:

- Macrotidal, undergoing significant tidal ranges (over four meters);

- Microtidal, undergoing lesser tidal ranges;

- Non tidal, not influenced or under negligible tidal influence. 


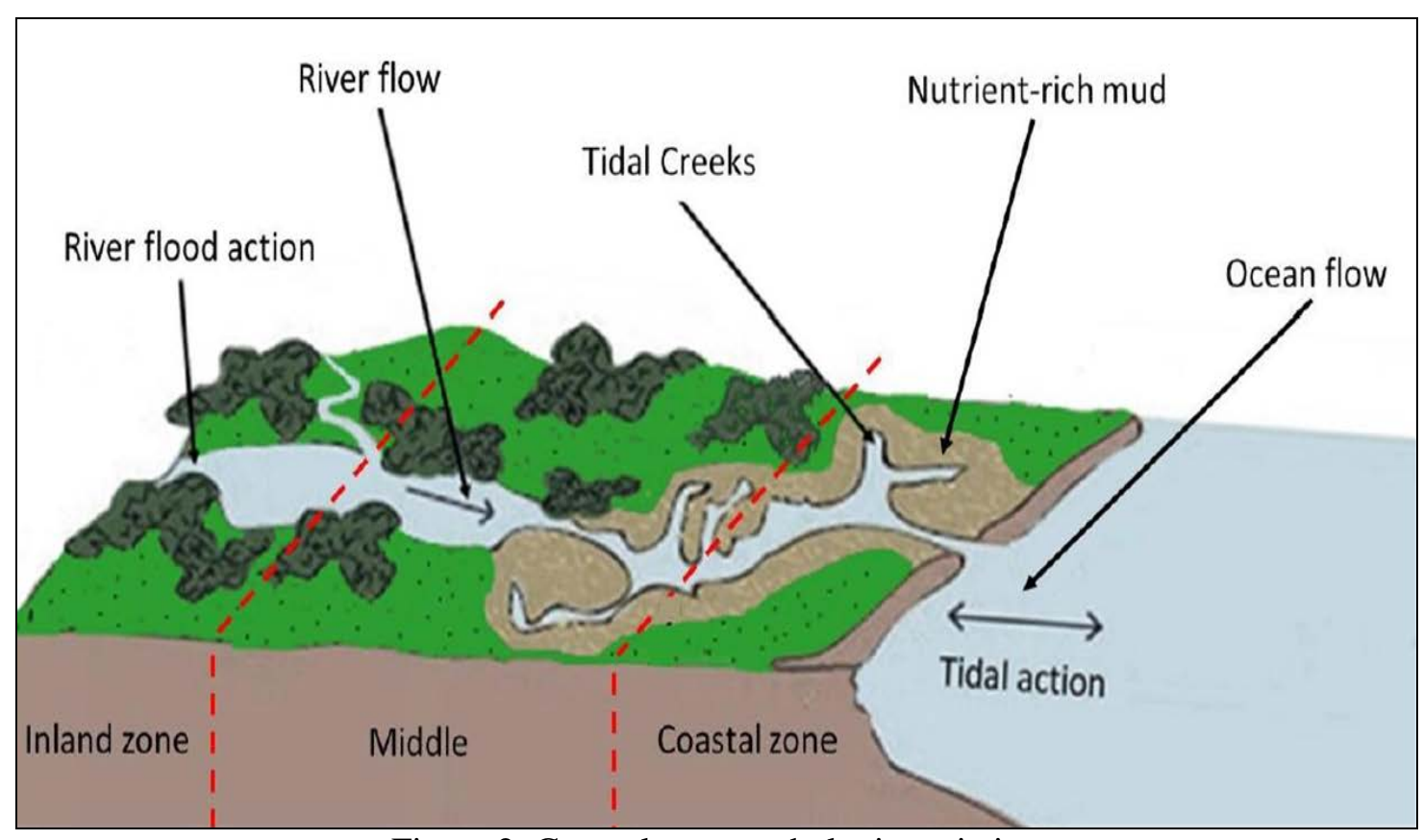

Figure 2: General geomorphologic variation between inner and coastal estuary portions.

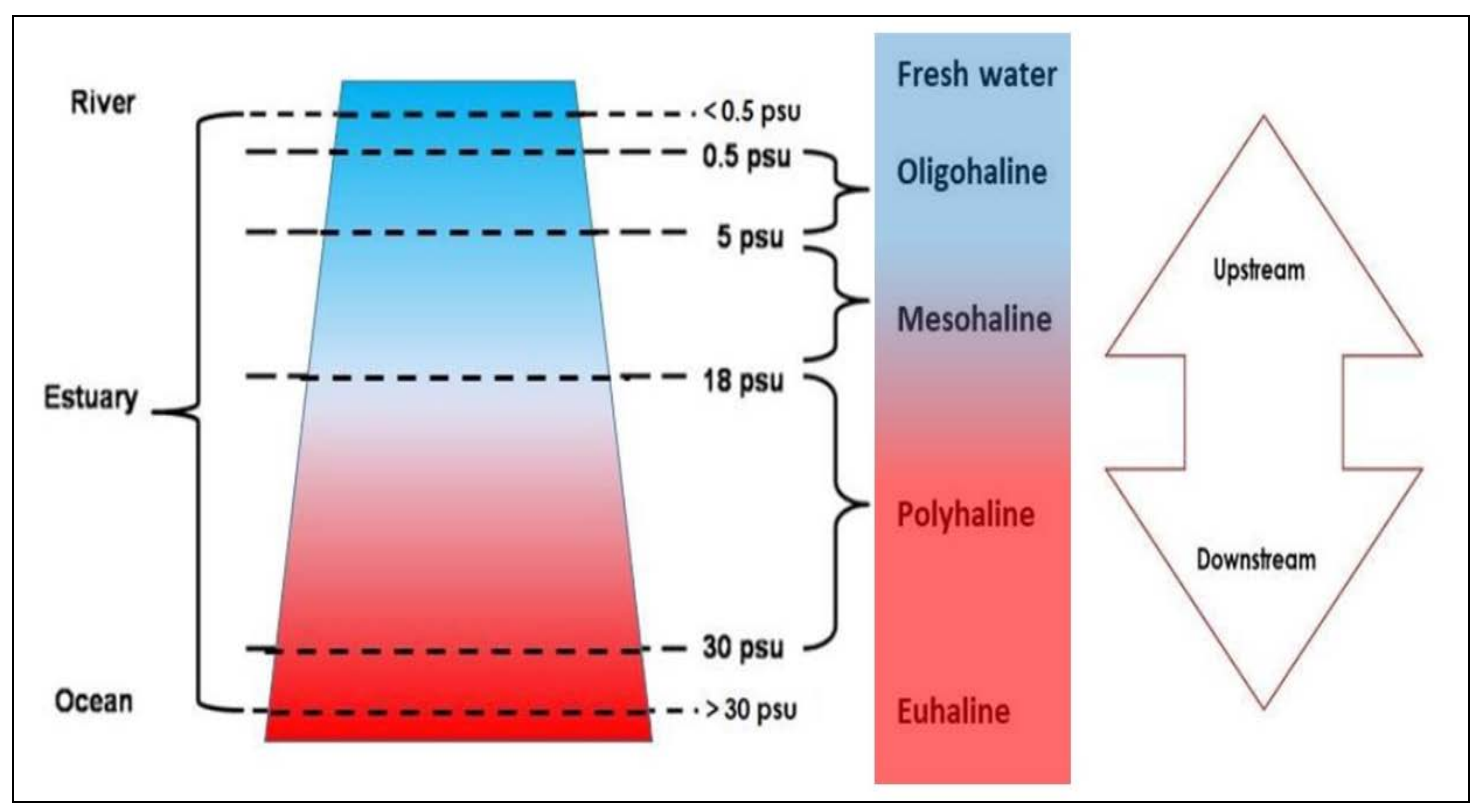

Figure 3: Estuarine up-down stream salinity gradient and related ecological sectors; psu corresponds to one part of NaCL per thousand parts of water. 


\section{MATERIAL AND METHODS}

\section{Research questions and objectives}

This work is aimed to develop a spatial-temporal predictive model based on the current and potential vegetation of estuaries, following a dinamico-catenal approach. This approach aims to represent three levels of organization of the vegetation: communities' organisation (associations), dynamic trends (series), and landscapes (geoseries).

The main research questions are the followings. Which geographical and ecological characteristics influence the vegetation patterns in the estuaries? How to classify estuaries according to vegetation characteristics (traits, distribution, and diversity) and their models? It is possible to define a generic common model of ecological gradients and landscapes plants from estuaries? The cartography process is performed to evaluate surfaces from tessellar units (sigmeta) and catenal units (geosigmeta).

This raises some additional questions about the potential and current vegetation. How can secondary communities help to characterize estuarine vegetation series? To what extent the current vegetation communities are in balance with the natural or artificial dynamics? This thesis also aims to study ecological and geographic systems in order to deepen knowledge of vegetation and ecosystems, in order to develop a synphyitosociological and cartographic methodology of the vegetation of the French Atlantic estuary systems.

\section{General concepts and definitions}

Phytosociology or simply plant sociology study the groups of plant species that usually grow together (phytocoenois, synusiae, plant communities, or phytoassociations) (Rivas-Martínez, 1976; Béguin et al., 1979; Tüxen, 1979; Géhu and Rivas-Martínez, 1981; Schwabe, 1989; Gillet et al., 1991; Theurillat, 1992a, b; Lazare, 2009; Biondi et al., 2011). The basic unit of studies in classical phytosociology is the plant association which constitutes a homogeneous community of plants in a homogeneous environmental unit. The plant association (or phytoassociation) is a plant community in equilibrium with the environment, characterized by a specific ecology, floristic composition, and aspect. This allows considering each plant association as original phenomena from a physiognomic, floristic, ecological, dynamic, and historical point of view (Tüxen, 1973, 1978; Falinski, 1986, 1998, 1999; Falinski and Pedrotti, 1990). Phytosociology organises plant communities in syntaxonomic units (syntaxa), which likely the taxonomical ranks are hierarchically organized at various levels. In plant associations, progressive dynamics are related to primary or secondary successions. The dynamics, on the other hand, are negative when they are related to phenomena of regression and degeneration. They are stable when they are related to fluctuation (anthropogenic or natural). In the vegetation series, the positive dynamics are oriented towards successions, passing from the current state to one with presumably higher in environmental balance (increasing both the structure complexity and of accumulated biomass). Conversely, negative dynamics tend to move away to this balance, reversing these characteristics.

Plant associations constitute the first level analysis of the plant landscape. Synphythosociology (or phytosociology of the landscape) includes the study of all plant associations in the landscape (Guinochet, 1973; Géhu and Rivas-Martínez, 1981; Géhu, 1991; De Foucault, 1984; Weber et al., 2000; Dengler et al., 2008; Dengler, 2017). Landscape phytosociology focuses on the description and classification of vegetation series in an ordered system, looking for a standard hierarchical system. By its holistic nature, this integrative system is useful for developing tools for monitoring ecosystems, conservation measures, functionality, habitats assessment, natural heritage, and biodiversity threats (Pedrotti, 2013; Cristea et al., 2016). 
In the field of the land management, it is possible to measure the status of the environment, evaluating the threats relying on the degree (impact) of land uses, following the degree of artificiality or naturalness of the landscape. The landscape phytosociology allows to integrate the vegetation dynamics by describing the trajectories of the series vegetation. Since the 1970s, the novelty has been characterized by a greater and increasing integration effort of geographic and ecological data (with landscapes, land use and other environmental data) followed by the creation of a large set of based on vegetation thematic maps. Classic integrated phytosociological studies correspond to the integration in a spatial-temporal way of the vegetation features (integrated phytosociological maps). Another possible integration type is the ecological integration, considering the integration with other thematisms (e.g.: environmental, social, agronomic, geographic, geological, soil, climate, and fauna) (Pedrotti, 2013; Cristea et al., 2016). The integration of these themes recalls, among other things, the definition of "geoarchitecture", a term used by the architect Le Corbusier at the beginning of the 20th century (Petrilli, 2006). Concept inspired in some way by some eminent scholars like Maestro Martino (Martino de’ Rossi), Anthelme Brillat-Savarin, Hannah Glasse, Pellegrino Artusi, about Gastronomy. In fact, in a broader sense, the term Gastronomy, meaning it as the study of the relationship between culture and food in an interdisciplinary science that involves biology, agronomy, anthropology, history, philosophy, psychology, and sociology. Resuming, it is possible to distinguish some subtypes of phytosociological maps: maps of real vegetation/syntaxonomic units; and maps of potential vegetation/climatic syntaxonomic units). The integration of these types of vegetation maps corresponds to the classical integrated maps of vegetation, where the vegetation is integrated in time and space, and the current vegetation is represented within the potential vegetation colour shades. Ecological integrated vegetation maps are integrated with other thematic aspects (soil, geology, etc.). Geosynphytosociological maps (geosigmetal maps) correspond to the vegetation complexes maps.

From a morphological point of view, an estuary is the portion of a river where the effects of the sea (or ocean) are remarkable. The mouth is the part of an estuary that flows into the sea. In estuaries, the main environmental factors are due to the conditions of the flows and the chemical, physical, and biological properties of the water. Variations in water flow determine the dynamics of sedimentation and erosion, as well as variations in salinity. Tidal estuaries are typically characterized by their larger surfaces, according to the highest possible tide levels (Gibson, 1934; Pritchard, 1955; Cameron and Pritchard, 1963; Guilcher et al. 1982; Wells, 1995; Gnanadesikan, 1999; Valle-Levinson, 2010; Mann et al., 2013).

The further downstream estuary portion is characterised by salty water, and influenced by salinity tide, while the portion located further upstream, with fresh water, they correspond to the dynamic tide. The dynamics of estuaries are influenced by the seasonal cycles linked to the floods caused by the tides (downstream) and the inflow of water from the catchment area (upstream). The beds, meanders, swamps, banks, and terraces of estuaries are always subject to the dynamics of the currents that can reshape them (Hansen and Rattray, 1966; Owen and Odd, 1972; Lambiase, 1980; Amos and Mosher, 1985; Shi et al., 1995; Strang and Fernando, 2001; Orton and Kineke, 2001). In all estuaries, the bed, meanders, banks, and terraces are constantly reshaped by the water flows cycles; by continued or alternative filling/erosion of materials; by different water levels and different salinity values, by suspensions coming from river or from the sea, creating a "permanently unstable" area. This dynamism is reflected in unstable (stablyunstable) environments, subject to recurrent or occasional disturbances that could affect all biological expressions, including vegetation, and in meantime they could reshape the landforms and the hydrology, consequently making these systems as "plastic" environments. 
From a geographical, geomorphological, and ecological point of view, the estuaries represent a multiple gradient between inland (riverine) and coastal (marine) systems. They represent a transition from the salty environment that are more exposed to sea winds, towards freshwater environments, more sheltered and less mild. In large estuaries, the influence of rivers is more pronounced due to the larger and therefore more impacting river bodies. In smaller estuaries, the influence of the sea is dominant to the point to consider them like a bay, a gulf, a marina: a bend of the sea. (Romaña, 1994; Verger, 2005)

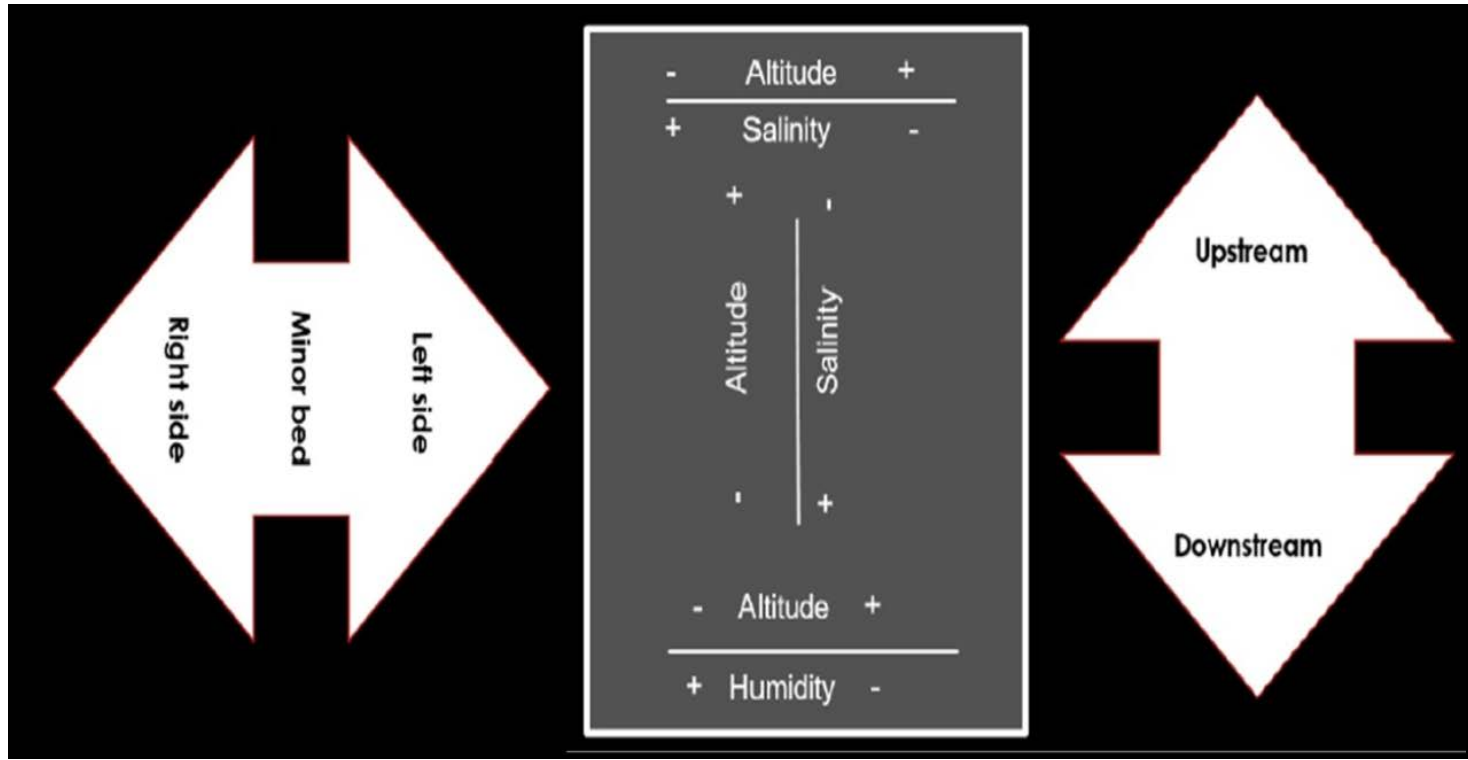

Figure 4: Schematization of estuarine geographical gradients and directions.

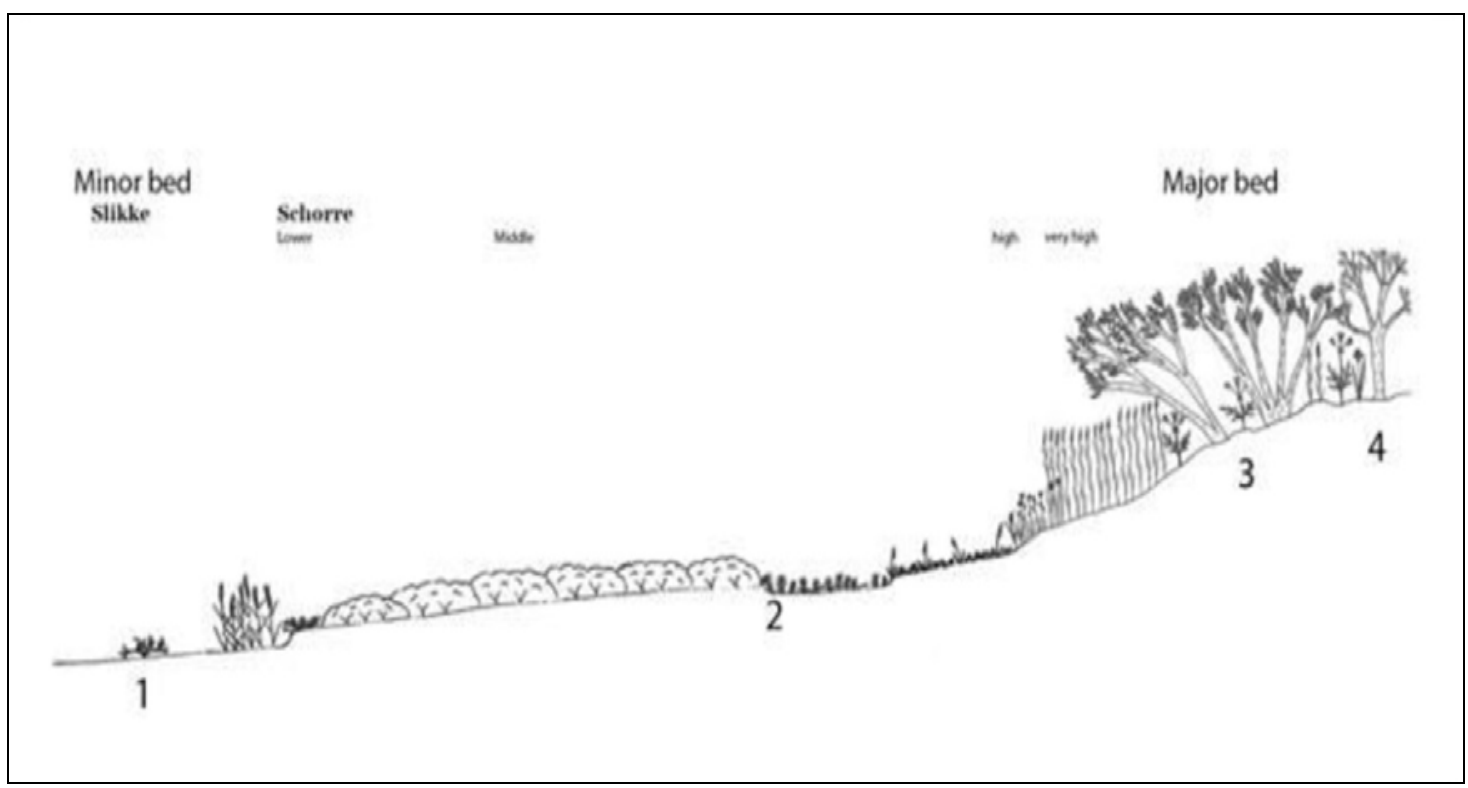

Figure 5: An example of complete phanerophyte gradient per geomorphological position, in salty estuarine portion. Vegetation is divided as expected from literature: from 1 to 2 non woody (permaseries) vegetation; to 3 to 4 woody vegetation (holoseries). 


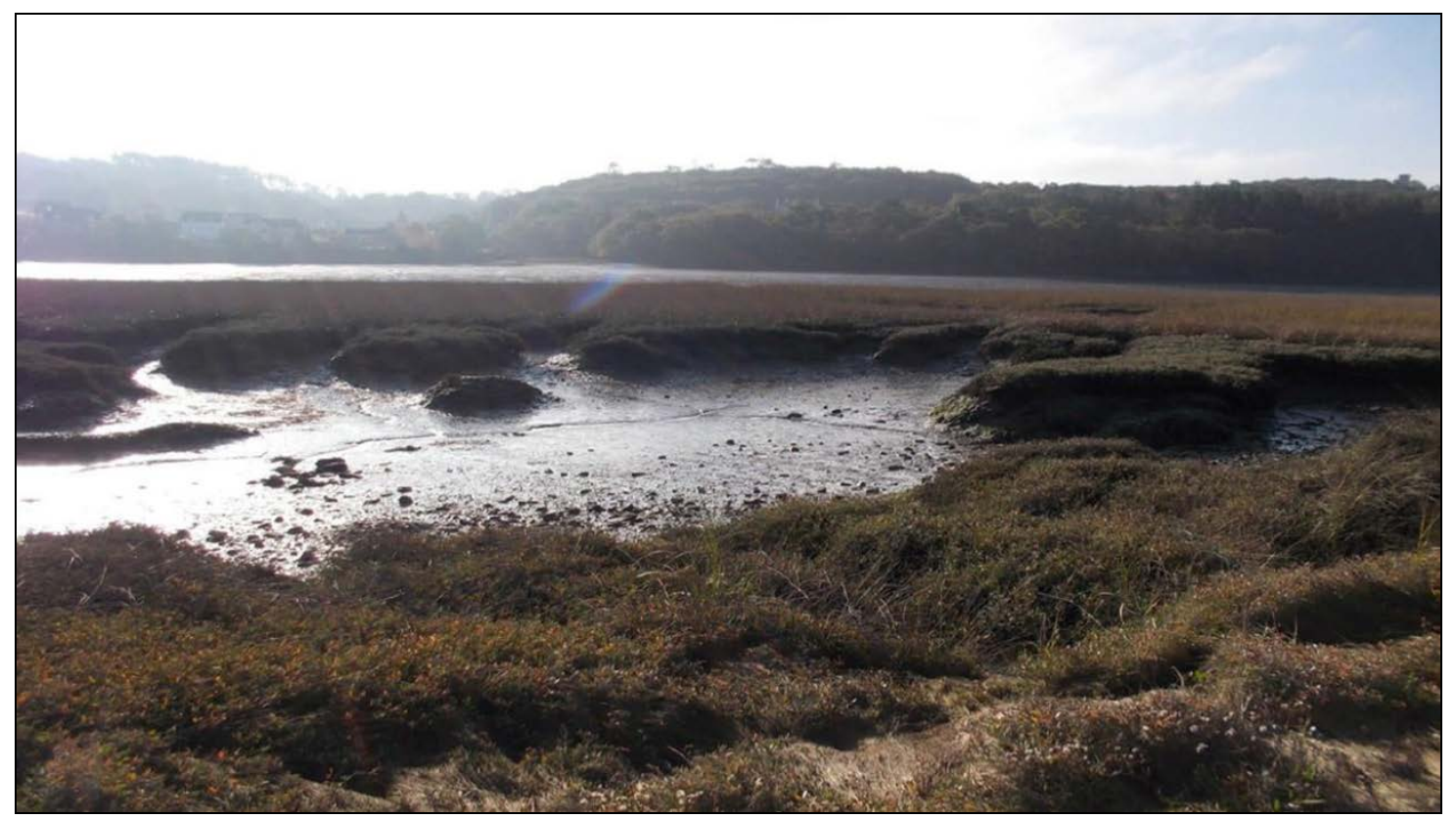

Figure 6: Aulne Estuary lower portion. The salt mud and meadows community, from glasswort, up to Halimione portulacoides coenoses, on salt mud tidal creeks.

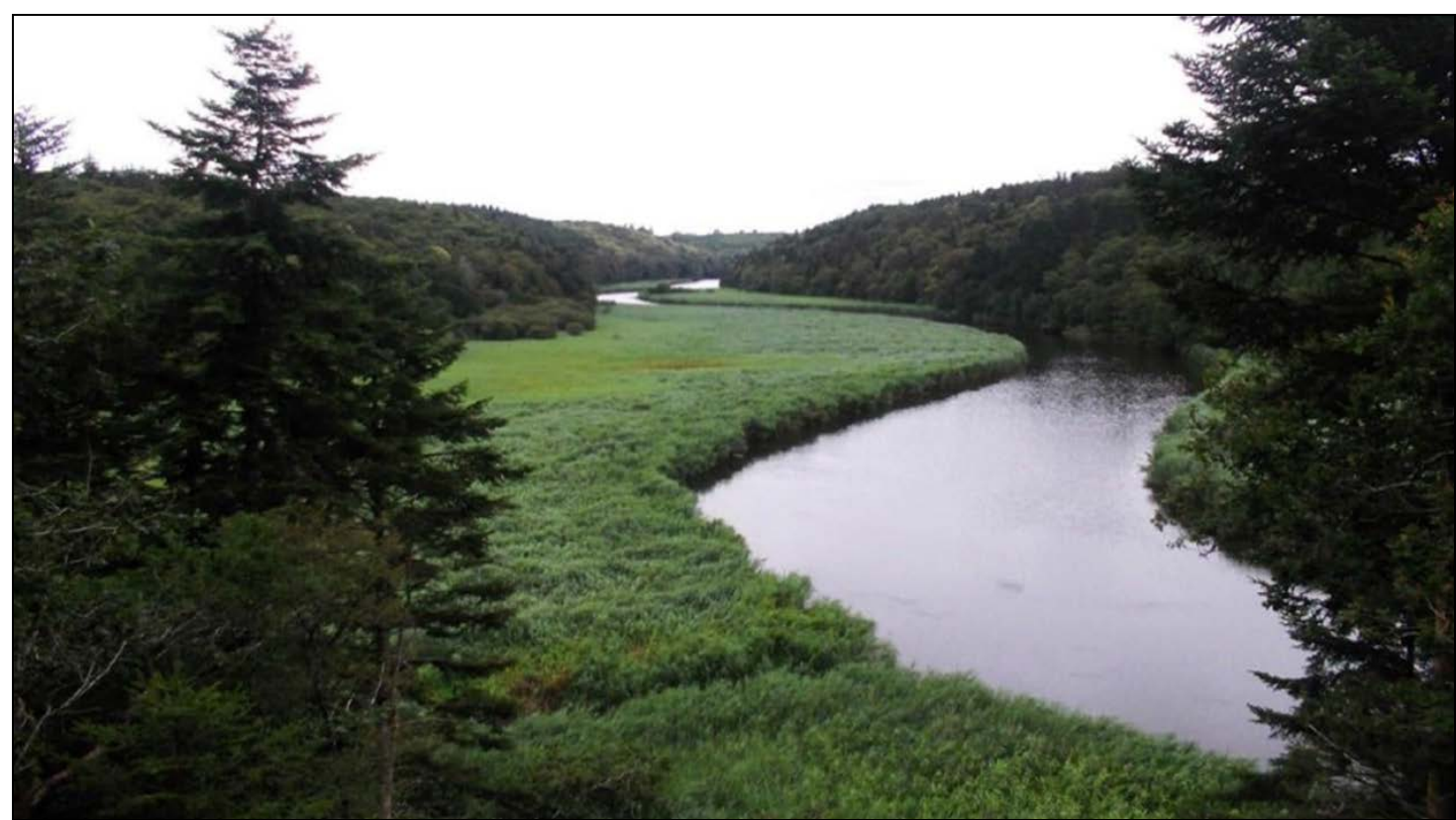

Figure 7: Laïta Estuary middle portion. From minor to major riverbed: the reed bed community (in large sense); Salix atrocinerea marshy forests (lower forest); and Fraxinus excelsior forests (upper forest). The zonal forests is characterised by Fagus sylvatica, out of the estuary. 


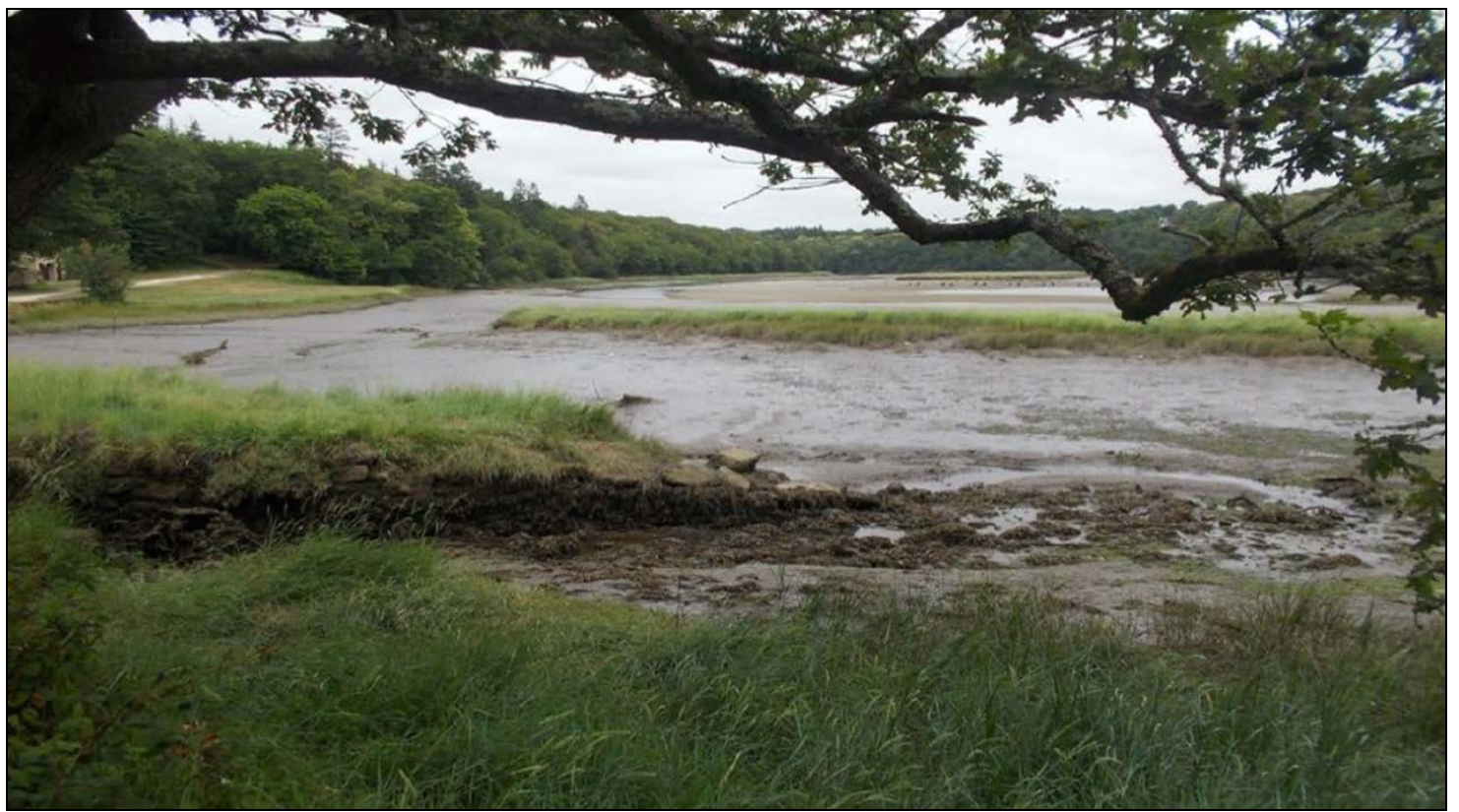

Figure 8: Laïta Estuary, St. Maurice. The contact between salt mud and meadows community (Elymus repens and E. athericus grasslands) and mesic forests community (Fraxinus excelsior and Quercus robur); on sandy-mud salt tidal creeks. At the bottom, the estuarine macroalgal tidal community.

\section{Study area}

The study area corresponds to the French Atlantic coast, located between the Basque Country (Iberian-French border) and Flanders (Franco-Belgian border), characterized by an oceanic climate (Fig. 9).

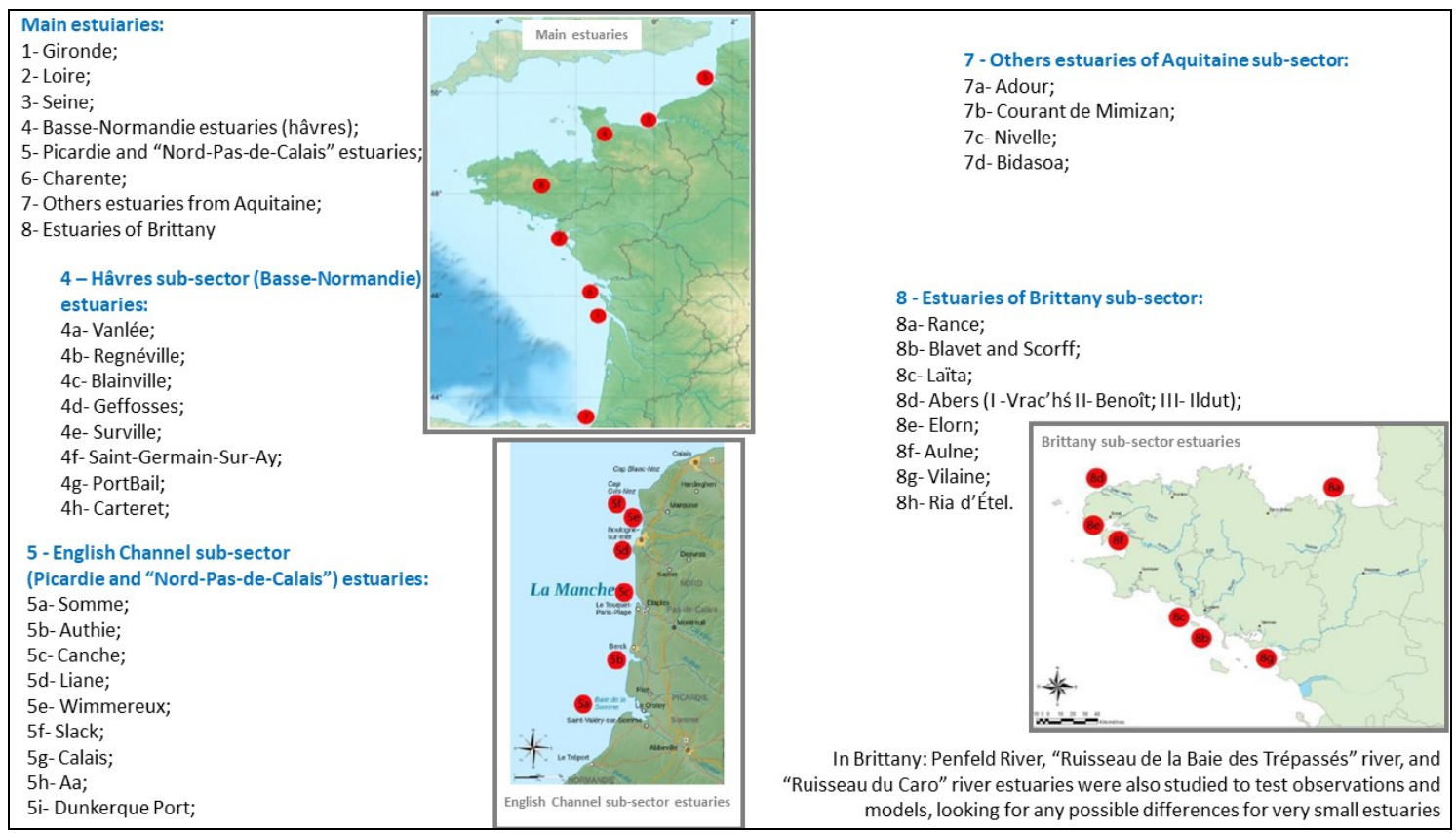

Figure 9: Estuaries sectors of study. 
Among the largest estuaries studied are: Gironde, Loire, Seine, and Charente. Among others from Basse-Normandie (Hâvres) are: Vanlée, Regnéville, Blainville, Geffosses, Surville, Saint-Germain-Sur-Ay, PortBail and Carteret. Among the estuaries of Picardy and the Nord-Pas de Calais are: Somme, Authie, Canche, Liane, Wimmereux, Slack, Calais, Aa, and Port of Dunkerque. Among the other estuaries of Aquitaine are: Adour, Courant de Mimizan, Nivelle and Bidasoa. Among the estuaries of Brittany are: Rance, Blavet and Scorff, Laïta, Abers (I-Vrac'h, II-Benoit, III-Ildut), Elorn, Aulne, Vilaine, and Ria d'Étel.

\section{Data analysis}

The vegetation series were named after the head-series association, while the geoseries were named after the most representative head-series association. For the secondary facies, we tried to identify potential vegetation. Consequently, semi-natural and artificial formations have been aggregated with head series formations into their relative series.

The preliminary work was carried out on all estuaries based on bibliography, aerial photos, topographic maps, maps of the intertidal zone, thematic maps related to vegetation, maps of habitats, land use, and protected areas), allowing us to summarize the available data on biotic and abiotic factors; and also to define a first ecological characterization, a first model of the estuary system and to create a first database to have initial elements of hypothesis, reflection and discussion about it. Particular attention was given to the characterization of vegetation and its cartography, as well as the observation of the role of ecological gradients, the dynamics of vegetation and the understanding of the anthropogenic pressure exerted.

A selection of estuaries was carried out to carry out field surveys, to develop the typology and cartography of the vegetation series and geoseries. The phytosociological and geo-reliefs were carried out to identify the different series, geoseries, and geopermaseries, to describe the distribution of vegetation in the landscape, and possibly highlight any synendemic elements or, conversely, any similarities (invariant elements) between estuaries.

The data cartographic processing has allowed us to develop a spatial model that allows us to represent the general organization of the estuary vegetation based on the associated ecological gradients. Not always has been possible to describe all the trajectories and dynamics of vegetation, due to the lack of historical data or because the land use is so marked on large surfaces to the point of altering the expression of vegetation or the shapes of the landscape and hence the potential of vegetation (drainage, erosion, deforestation, desertification, loss of natural species, introduction of exotic species). The map of potential vegetation (represented by series, geoseries, and geopermaseries of vegetation) was integrated with the symphisociological and phytosociological surveys (real vegetation) describing the composition of the various mapped units. Special cases can be represented by symbols on the cards or described. The vegetation maps were created using the QGIS software (version 2.18.14).

Umbrothermic, climatic, and bioclimatic analyses were performed using data from the MeteoFrance and WorldClim databases, with the aim of framing the estuaries and analysing the climatic micro-variations in the estuaries.

\section{RESULTS AND DISCUSSION}

The main factors that characterize estuaries and their ecological gradients are the salinity and the water content of the substrate (sediments/soil) (Cianfaglione, 2018). Other physical factors can determine differences, peculiarities or exceptions: substrate size, slope, sea winds, microclimatic variations, human impact. Each estuary is an original system, due to a unique combination of its geographical, ecological, uses history and dynamic characteristics, combined with present and past human impact. In estuaries, ecological gradients follow 
geographic and morphological variations in two directions: longitudinal (from valley to mountain) and transverse (from minor to major bed). In both cases, we go from lower topographical levels to higher levels, consequently the salinity decreases, as does the soil moisture content. Following the direction of the topographical levels, the higher you go, the more you can find a common tendency in both directions regarding the expression of the vegetation (from marshes and salty meadows to the forests of greater ash and English oak). In the two directions (longitudinal and transverse) the influence of the tides tends to be less important further upstream, while, the precipitations (with the water table) increase their footprint. The transverse topographic gradient (minor-major bed) corresponds to a gradient of decreasing humidity (or flooding) and similarly also happens for salinity. Following these variations, we can found the following geomorphological compartments (Fig. 5): main channel, Slikke, Schorre and alluvial plain (Verger F., 1995; Géhu J.-M., 2009a, b)

In Slikke level (mudflats) we find a mud layer exposed at the tidal fringe, with very changing water level and salty conditions especially in the medium estuary. Here we can find non vegetalised mud or algal communities (micro and marco algal formations, compised the Maerl - or rhodolith, a coralline-like formation of red algae, found occasionally in less muddy and stonyest (pebbles) substrate. In the innermost portions of the estuary (freshwater portions) these communities are replaced by the lowest most freshwater amphibious plant communities (i.e. Apitum nodiflorum, Berula erecta, Veronica beccabunga, etc.).

In the Schorre level we can find a saltmarshes (tidal marsh), sited in the upper coastal intertidal zone between land and open saltwater or brackish water that is regularly flooded by the tides. It is dominated by dense stands of salt-tolerant plants such as herbs, grasses, or low shrubs (Adam, 1990; Woodroffe, 2002). In the innermost freshwater parts of the estuary these communities are replaced by uppermost freshwater amphibian vegetation (i.e. sedges and reeds) and by annual summer plant communities (i.e. Poligonum and Bidens species).

In the alluvial plain we can find the largest riverbed portion where forests can develops from riverine, to marshy and mesic types. In this level the human activities are wider (agriculture, livestock pastures, urbanisation, and industrial zones). Topography or soil differences (slope, drainage, frequency of floods, and the level of the groundwater) here can favour one or another potential vegetation, until reed-beds and others non-forest marshy/riverine communities. At this level, in upper topographical levels, floods can be annual, with very long frequencies (even centuries or millennia) or occasional (extreme events). The alluvial plain in the more coastal portion is more subject to winds and salt spray that could disadvantage the formation of tall forests, in favour of dwarf forest and bushes.

Under normal conditions, on this level, soft wood forest communities develops, dominated by ash trees ( $F$. excelsior and $F$. angustifolia) mixed with more hygrophilous species (willows, poplars and alder species), up to them forests increasingly become rich in hardwood species -then mixed with more mesophilic species (Acer sp. pl., Ulmus sp. pl., Prunus sp. pl., Betula sp. pl. and Quercus robur) until they become very rich in Q. robur. In extreme cases, it is possible to find also Q. petraea, Q. cerris and Castanea sativa presences mixed in the forest communities (in ecotonal conditions with non azonal forests). In more drained and thermophilic ecotonal conditions, also conifer trees could be found (in particular Pinus pinaster) and also Quercus ilex. About shrub formations (Prunetalia) in more drained conditions (upper topographic levels, or in sandier soils) we increasingly find the presence of Ulex Europaeus in the thicket. In more thermic coastal condition we can find an increasingly presence of Ligustrum vulgare or other coastal species of Ulex (dwarf thicket). Under tiny soils on acid substrate (or decalcified soils) we can found Erica species and Cyitssus scoparius in the thicket. In marshy and riverine condition the shrubland is composed by Salix species that 
(more rarely) are accompanied by the Frangula alnus species (in more fresh watery condition) and Rubus caesius (frequently remplaced by its hybrids) at same level, but in more drained conditions, we can find Euonimus europaeus.

According to the longitudinal topographic gradient, (coast to inland) three salinity compartments can be distinguished from the mouth upstream: salt, brackish, and fresh water.

Estuaries can be defined as ecosystems, but at the same time also as complexes of ecosystems characterized by fluid ecotones, with boundaries delimited in time and space (Fig. 4). The behaviour of an estuary varies greatly depending on the season, location, tidal strength, river flow, rainfall, wind, and deep-sea currents. The expression of estuary biodiversity is complex due to the presence of characteristics that coexist even if they could appear to be antagonistic (for example the influence of salt water and fresh water on the same surface, or the alternation of drought and aquatic conditions, sediment deposition and erosion, etc.). This ecological complexity induces a certain complexity of the habitats and therefore of the vegetation. Consequently, estuarine gradients can be highly variable and multidirectional, reflecting the complexity of each of these systems. The presence of species, plant communities and vegetation limits can be roughly defined by analyses over time and based on water bodies, taking the main channel as a reference (Figs. 5-8). As primary producers in the ecosystem, plants and plant communities are particularly sensitive to the phenomena that characterize the environment, and due to their physiological and biological characteristics they are considered good bio-indicators (sometimes known as macrophytes) especially for aquatic and mesic environments (as in the case of estuaries). In fact, the study of vegetation allows the short-term characterization of the environment and the monitoring of global changes in the long term, because plants are closely linked to the expression of biodiversity and therefore to environmental conditions, functioning as bio-indicators (Sender et al., 2014, 2017).

Out of a total of 36 identified estuaries, eight were selected for phytosociological and synphyto-sociological research (Charente, Loire, Vilaine Etel, Blavet-Scorff, Laïta, Aulne, and Elorn). The field work involved a 98,315 ha surface (Fig. 10). The data analysis and phytosociological synrelevés highlight two series and four geopermaseries, corresponding to 131 associations, 60 alliances, 43 orders, and 28 phytosociological classes. Three estuaries were selected to build the vegetation mapping and geoseries (Loire, Laïta, and Aulne). 74,433 ha were mapped, equal to two series and four vegetation geopermaseries. The phytosociological analysis does not claim to be exhaustive. In the estuaries, from the mouth to the freshwater portion, some variations and exceptions relating to the local geomorphology can be distinguished. The main variation follows the confinement of estuaries and the associated continuity (lateral, longitudinal, and vertical). In fact, the more the estuaries are of the confined type, the less the sequences of the vegetation series are evident (the series and geoseries tend to be more linear, discontinuous, nuanced, and thin), until they no longer allow the expression of one or more series, influencing the plant communities richness and the transgression. Considering that the floodplain is the largest floodable area, the problems of confinement and continuity therefore reflect on the human impact, as a result of artificial embankments, dams, drainages, reclamation, and backfilling. These changes block or affect hydrodynamics and geomorphology, with consequent exceptions related to vegetation expression.

The elaboration of phytosociological and synphytosociological tables, alongside the elaboration of vegetation maps, allowed us to validate and refine the initial hypothesis of ecological zoning in estuaries and to adapt it to series, geoseries, and geopermaseries, according to the cartographic principle of generalization. 
In the saltier areas, from the minor to the major bed, the marshes vegetation and salt meadows (Atriplici prostratae-Elymeto atherici geopermasigmetum) are installed, succeeded by the marshy willows to Salix atrocinerea (forests of Salix atrocinerea geosigmetum), in addition the Fraxinus excelsior forests (Fraxinus excelsior forest geosigmetum). Upstream, Salix atrocinerea tends to be replaced by Salix fragilis (Saliceto fragilis sigmetum) and further upstream by Salix alba (Saliceto albae sigmetum). In the estuary minor bed, the vegetation can express well in the most sheltered or residual conditions; in linear or punctual form, due to strong currents and changes in the water fronts. Due to these characteristics and the possible mixed accessions of fresh water at various levels, we have simplified the cartography of the aquatic vegetation in the Lemneto minoris geopermasigmetum. It has included the aquatic vegetation of the pools, the meandering springs, floodplains, and rivulets, including all the primary aquatic vegetation. Three vegetation subgroups can be distinguished (depending on the rather salty, brackish or freshwater character). Vertical continuity and related natural exceptions influence the expression of vegetation. For example, it is worth mentioning the influence of fresh water natural accesses in saline habitats, or the possibility of marshy vegetation in the greater bed or of humid meadows and marshes with little or no salt, which in summer dry up, being able to show a certain outcrop of salt during the dry season (salinizing).

In the saline part, geomorphology and hydrodynamics influence the expression of the vegetation based on the type of substrate and the morphological type of the mouth. The relative variations in the granulometry of the substrate depend on its stability (balance between sedimentation, and erosion). If the balance between deposition and erosion is not strong enough to continuously reshape the surface, the vegetation can install more easily; the mud can also settle between the pebbles and the sand, promoting the installation of the plant community linked to marshes and wet saline parts. The influence (transgression and contacts) of the vegetation of the sands creates a variant of this community that is enriched with species typical of the beaches and dunes. The same phenomenon occurs in the presence of rocky outcrops or overhangs of earth and related species. If the deposits move, there may be an almost total absence of vegetation, scattered and less developed specimens, fragments of vegetation influenced by more stable deposits or by accessions of fresh water, as noted in the estuaries of the Loire, the Ria d'Etel, the Laïta, the Blavet-Scorff, and the Vilaine.

If the river is very open to the sea, or if the tidal flow is clearly greater than that of the river, the estuary behaves more like a sea bay (this is the case of Étel); the vegetation linked to salty waters can be more easily observed and the oligo to mesohaline Schoenoplectus tabernaemontani formations appear only punctually. In areas disturbed by human activities, due to deforestation and different uses, large surfaces may not express a seed. In other cases there has been a change in the vegetation series (displacement) upstream or downstream, following a change in the flood or salinity front, factors which can also cause the death of some species or the degeneration and regression of communities plants (Loire and Charente). In other cases, in salty or brackish areas, due to dams that prevent or slow down the rise of the salinity front, a marked presence of Alnus glutionsa can be noted, replacing forests with Salix atrocinerea (in more swampy conditions) or even Fraxinus excelsior forests (in less swampy conditions). This phenomenon has been observed in the lower part of the Erdre in the Loire Estuary and near the Folgoat chapel (Landévennec), near the old tide mill, in the Aulne Estuary. Similarly, reed beds and other herbaceous formations of fresh water can be found in the estuaries of Ria d'Étel and Laïta, in areas of salinity, but no longer subject to salt as they are located upstream of the lateral dams. In the Vilaine Estuary, upstream of the Arzal Dam, there is now a freshwater vegetation in the minor bed, in a former halophilous area. The Guily Glaz Dam, built in the Aulne Estuary to limit the impact of floods on the watershed, limits the 
expansion of water in the oligoaline zone, reducing the surfaces and the expression of vegetation linked to dynamic tides. The displacement of the willow series (Salix fragilis and Salix atrocinerea) to both banks of the Loire, between Saint-Nazaire, Nantes, and Donges is observed as a result of the artificial accumulation of sediments after the channel deepening into the estuary for channelling due to navigation (Figs. 10-13).

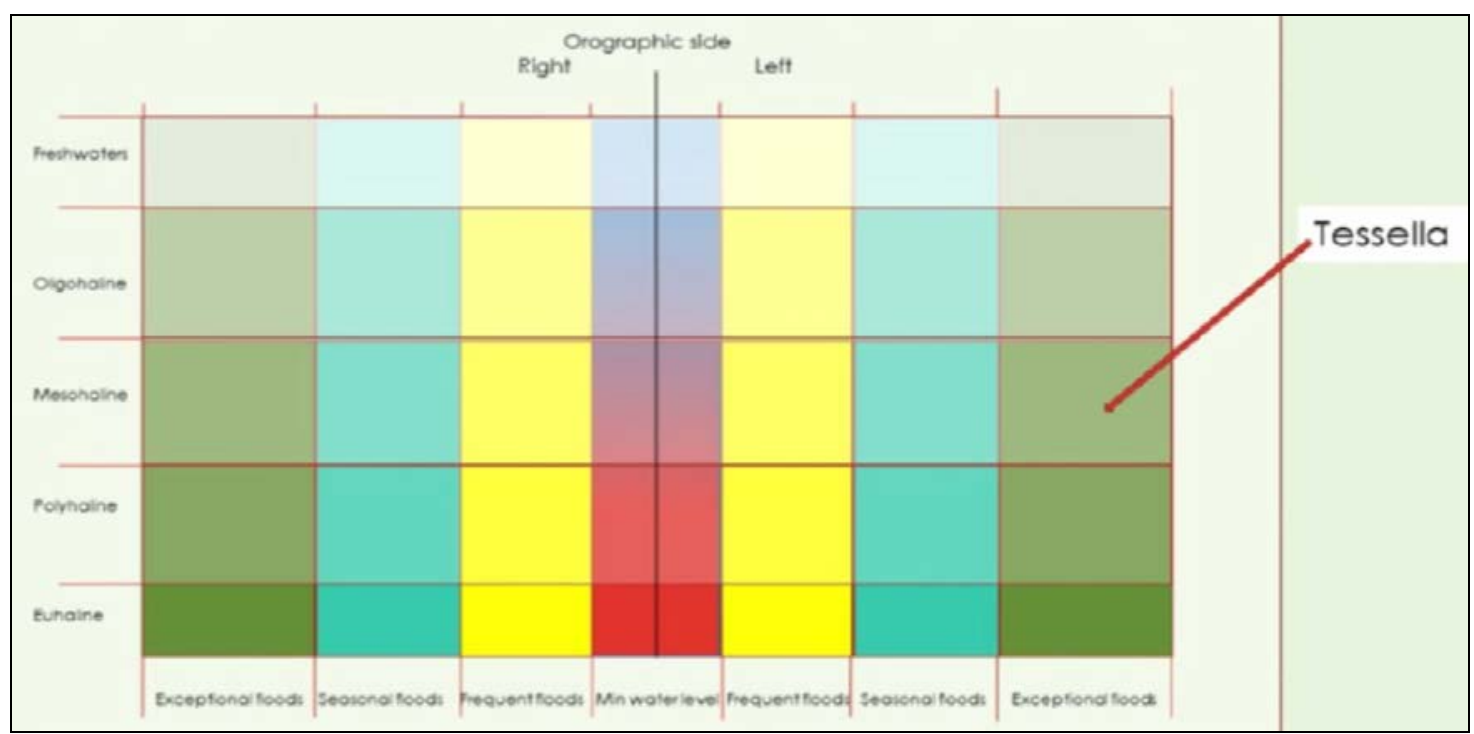

Figure 10: Theoretical square grid system of the expected ecological compartments distribution of estuaries, obtained crossing floods, and salt levels.

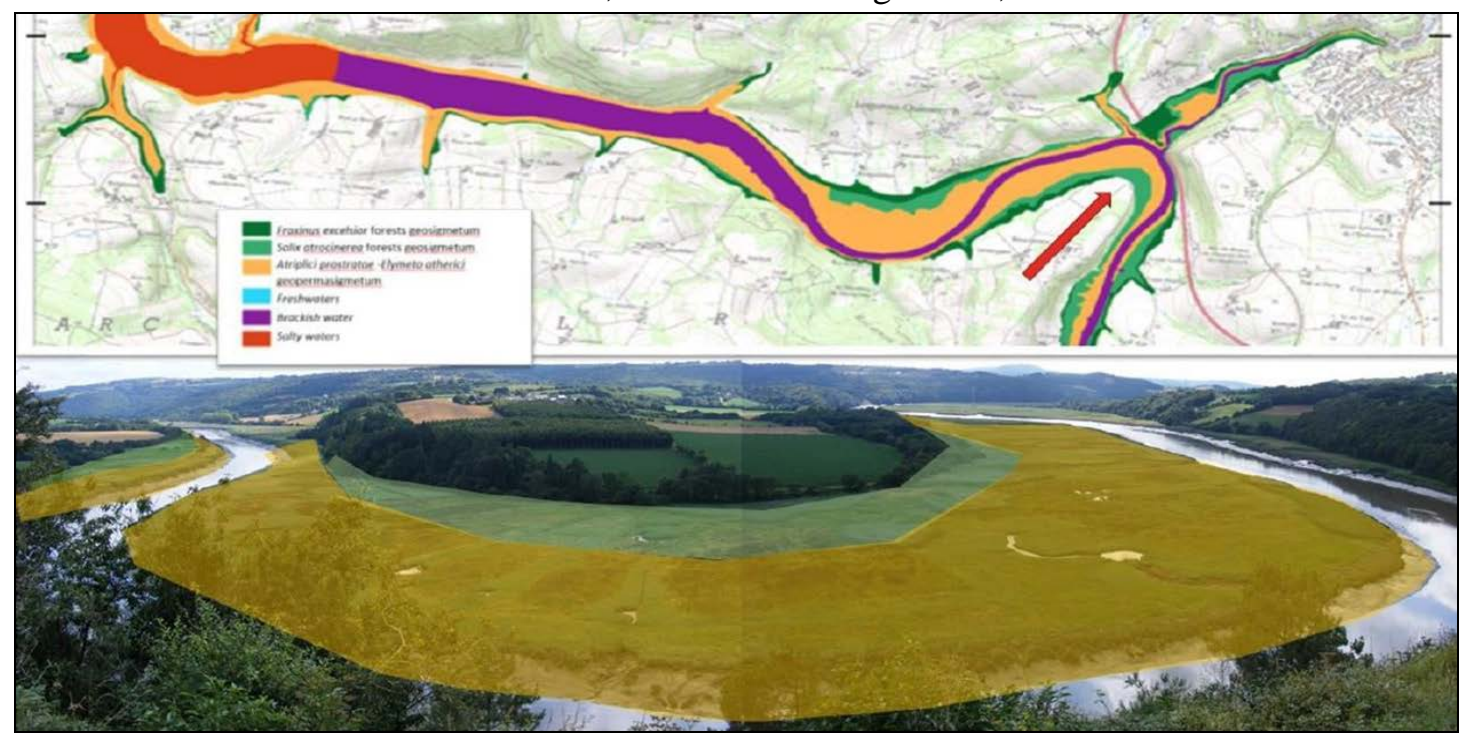

Figure 11: Plant map spatialization example of serial complexes in brackish water portion of Aulne Estuary. Down, in detail is represented the point indicated in the cartography with the red arrow. The zonation from minor to major riverbed is: acquatic environments (riverbed and pools), salt marshes and meadows (Atriplici prostratae-Elymeto atherici geopermasigmetum) brackish variant, Salix atrocinerea sigmetum, and Fraxnius excelsior forests geosigmetum. 


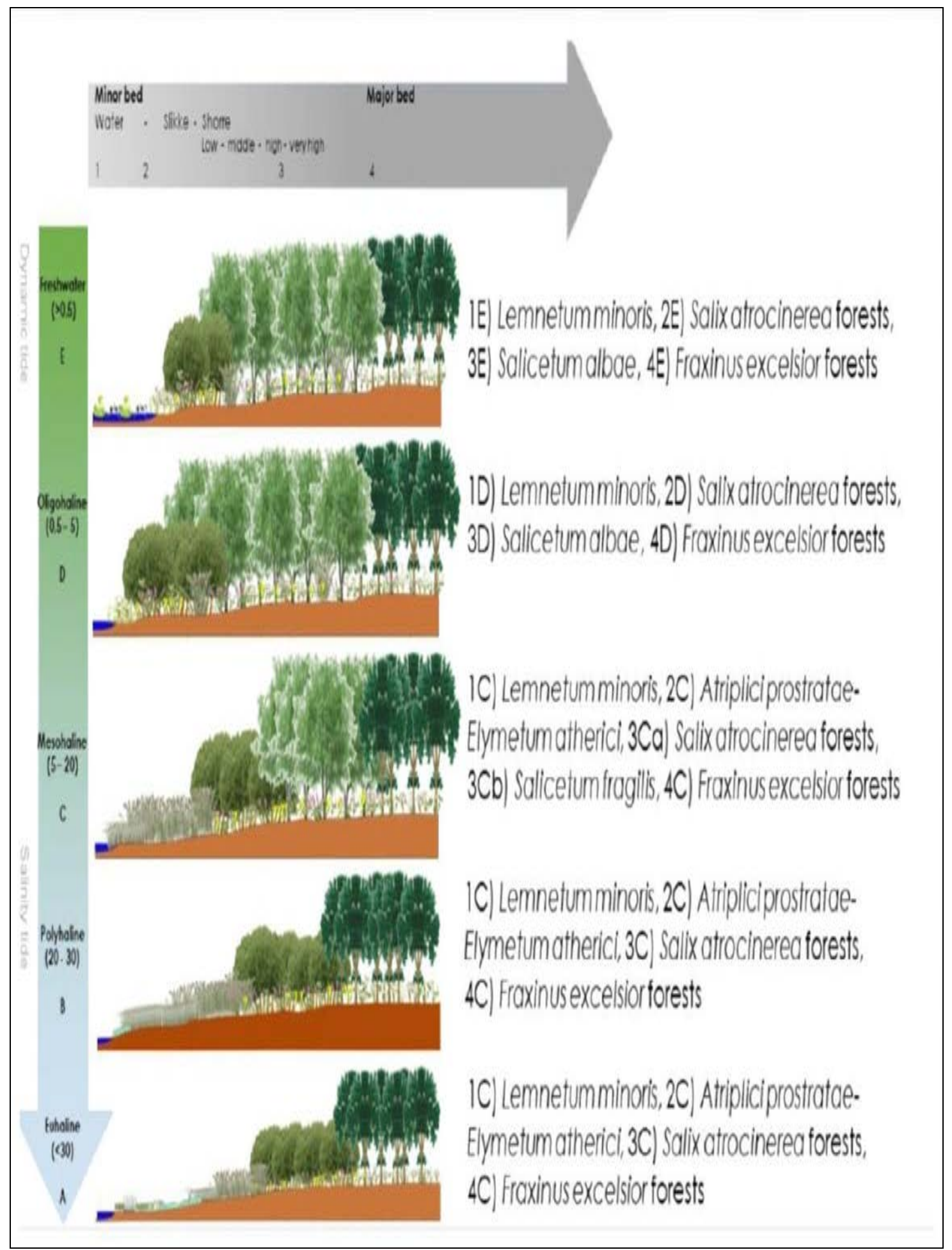

Figure 12: Plant association general transect model per Up-Down and Left-right ecological transect for salinity sector. 


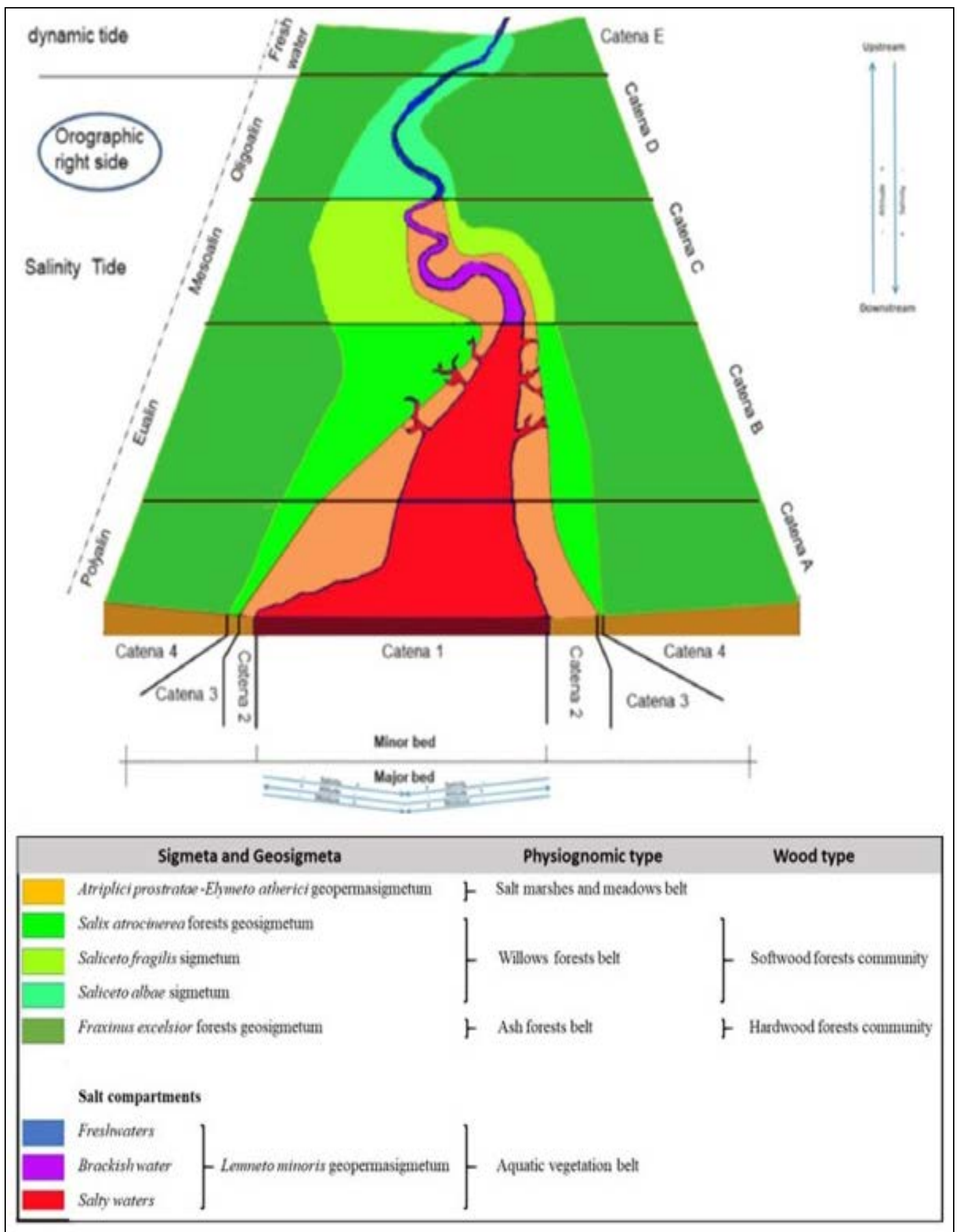

Figure 13: Theoretical series/catenas scheme of an estuary after our synphytosociological elaboration. 


\section{CONCLUSIONS}

As part of the CarHAB program, this research allowed to propose a first phytosociological and serial typology, a cartography methodology and model characterization (general and tidal estuaries) on the distribution and organization of the vegetation of the French Atlantic estuaries. Studied estuaries resulted exposed to a wide range of different human impacts. The results and the employed research methodology elements can be used on a small and large scale and can be applicable to other estuaries.

A perspective to be developed concerns the inductive acquisition of data in the field, mobilizing tools to measure ecological gradients (salinity, $\mathrm{pH}$, humidity), to produce quantitative models that allow to search for mathematical correlations with the deductive models already produced and apply them to variations in the vegetation, detectable manually in the field or by remote sensing. The implementation of diachronic monitoring of vegetation would complete the knowledge of floristics, $\beta$-biodiversity, syntaxonomics, and the chorology of estuarine vegetation. It would also be interesting to correlate the data on the distribution of vegetation with the monitoring of the presence of microorganisms, plankton, and variations in biomass productivity. On the test sites, it would be interesting to give each set of vegetation the opportunity to freely express its natural dynamics for applications related to habitat management and conservation, in order to better understand the potential of the plant landscape and optimize the methodologies for evaluating the human impact, mobilizing the concepts of naturalness, artificialization and resilience. A research perspective, already launched under the CarHAB program, concerns the use of ecological white funds and to facilitate tissue divisions. Recently, the ISTHME laboratory of the University of Saint-Etienne organized a test to identify the most relevant indicators to be modelled in the context of the spatial delineation of vegetation and other research carried out within the CarHAB project. This makes it possible to identify ecological reference points that could facilitate the recognition of vegetation limits and try to automate the work techniques as much as possible. Another perspective concerns the refinement and resolution of vegetation cartography and synphysociology through digital skills, using computer programs, satellite images and remote sensing, to provide more quantitative data and develop the comparison with qualitative data so as to develop further applications for land management.

Our work mainly focuses on environments and habitats of international importance ("Natura 2000" habitat and the Ramsar Convention). The same habitat could be represented by associations of plants with different ecological values, which indicate different degrees of artificialization and rarity. For this reason, more in-depth phytosociological and synphysociological research could allow to better understand the evolution and evaluate the natural heritage, based not only on the presence of species, but also on plant associations, and on the series of vegetation.

\section{ACKNOWLEDGEMENTS}

The author wishes to thank all the people involved at different levels in this $\mathrm{PhD}$ thesis research and in the $\mathrm{PhD}$ course. 


\section{REFERENCES}

1. Adam P., 1990 - Saltmarsh Ecology, Cambridge University Press, New York, 461.

2. Amos C. L. and Mosher D. C., 1985 - Erosion and deposition of fine-grained sediments from the Bay of Fundy, Sedimentology, 32, 815-832.

3. Bănăduc D., Curtean-Bănăduc A., Pedrotti F., Cianfaglione K. and Akeroyd J., (eds), 2020 Human impact on Danube Watershed biodiversity in the XXI Century, Hardcover ISBN 978-3030-37241-5, eBook ISBN 978-3-030-37242-2, DOI 10.1007/978-3-030-37242-2, 107 illustrations in colour, Springer International Publishing, first edition, 437.

4. Béguin C., Géhu J.-M. and Hegg O., 1979 - La symphytosociologie: une approche nouvelle des paysages végétaux, Documents phytosociologiques, IV, 49-69. (in French)

5. Biondi E., 2011 - Phytosociology today: methodological and conceptual evolution, Plant Biosystems, 145, 19-29

6. Borja A., Basset A., Bricker S., Dauvin J., Elliot M., Harrison T., Marques J., Weisberg S. and West R., 2012 - Classifying ecological quality and integrity of estuaries, in Wolanski E. and McLusky D. (eds), Treatise on Estuarine and Coastal Science, Waltham Academic Pres, 125162.

7. Cameron W. M. and Pritchard D.W., 1963 - Estuaries, in Hill M. N. (ed.), The Sea, John Wiley and Sons, New York, USA, 2, 306-324.

8. Cianfaglione K., 2018 - Plant landscape and models of French Atlantic estuarine systems, PhD Thesis, Universite de Bretagne Occidentale (Brest, France), SHS Ecole Doctorale No. 604, en co-tutelle avec L'Universita Degli Studi di Camerino (Camerino, Italy), SAS School of advanced studies, 353.

9. Clergeau R. and Blanc N., 2013 - Trames vertes urbaines. De la recherche scientifique au projet urbain, Le Moniteur Ed., Antony, France. 337. (in French)

10. Cristea V., Gafta D. and Pedrotti F., 2016 - Fitosociologia, Temi, Trento, Italy, 408.

11. Day J. W. Jr., Yanez-Arancibia A. and Kemp W. M., 2012 - Human impact and management of coastal and estuarine ecosystems, in Estuarine Ecology, second edition, Day J. W. Jr., Byron C., Crump W., Kemp M. and Yanez-Arancibia A. (eds), Wiley-Blackwell by John Wiley and Sons, Inc.: 483-497.

12. De Foucault B., 1984 - Systématique, structuralisme et synsystématique des prairies hygrophiles des plaines atlantiques françaises, Thèse de Doctorat, Université de Rouen, Université de Lille II, I et II. (in French)

13. Dengler J., 2017 - Phytosociology, in Richardson D., Castree N., Goodchild M. F., Kobayshi A. L., Liu W., Marston R. A. (eds), The international encyclopedia of geography: people, the Earth, environment and technology, Chapter: Phytosociology, Wiley-Blackwell Publishing, Chichester, DOI: 10.1002/9781118786352.wbieg0136.

14. Dengler J., Chytry M. and Ewald J., 2008 - Phytosociology, in Jörgensen S. E. and Fath B. D. (eds), Encyclopedia of ecology, Chapter: Phytosociology, Elsevier, doi: 10.1016/B978008045405-4.00533-4.

15. Di Pietro F., Mehdi L., Chaudron C. and Moyon F., 2017 - Le lit endigué de la Loire moyenne: de l’image de fleuve sauvage à la reconnaissance de son caractère anthropisé, Norois, 242, 7-23, https://doi.org/10.4000/norois.6030. (in French)

16. Falinski J.-B., 1986 - Vegetation dynamics in temperate lowland primeval forests, Ecological studies in Bialowieza forest, Geobotany, 8, 1-537.

17. Falinski J.-B., 1998 - Maps an anthropogenic transformation of plant cover (maps of synanthropization), Phytocoenosis, 10, 15-54.

18. Falinski J.-B., 1999 - Geobotanical cartography: subject, source basis, transformation and application fundamentals of maps, Phytocoenosis, 11, (Suppl Cart Geobot 11), 43-65.

19. Falinski J.-B. and Pedroti F., 1990 - The vegetation and dynamical tendancies in the vegetation of Bosco Quarto, Promontorio del Gargano, Italy, Braun-Blanquetia, 5, 1-31. 
20. Géhu J.-M., 1991 - L’analyse symphytosociologique et géosymphytosociologique de l'espace, Théorie et méthodologie, Colloques Phytosociologiques, Phytosociologie et Paysages, Versailles, 1989, XVII, 11-45. (in French)

21. Géhu J.-M., 2004 - La symphytosociologie trente ans plus tard (1973-2003) - Concepts, systématisation, applications. Bulletin de la Société Botanique du Centre-Ouest, NS, 35, 63- 80. (in French)

22. Géhu J.-M., 2006 - Dictionnaire de sociologie et synécologie végétales, Édition Cramer J., Berlin, Stuttgart, 899. (in French)

23. Géhu J.-M., 2009a - Dunes et prés salés de la réserve naturelle de la Baie de Somme (80, France), Analyse phytosociologique d'une remarquable bioconodiversité récente, Journal de botanique de la societé botanique de France, 48, 21-46. (in French)

24. Géhu J.-M., 2009b - Les prairies saumatres de la reserve naturelle de la Baie de Somme (80, France), Bulletin de la societe botanique du centre-ouest, NS, 39, 175-186. (in French)

25. Géhu J.-M., 2010a - Sur le centenaire d'une science d'actualité, la phytosociologie moderne, et quelques jalons historiques de son développement, Journal de Botanique de la Société Botanique de France, 50, 33-57. (in French)

26. Géhu J.-M., 2010b - À l'occasion de son centenaire, rappel de l'origine et du développement de la Phytosociologie moderne en un choix de dates-clés, Bulletin de la Société Botanique du Centre-Ouest, NS, 41: 233-248. (in French)

27. Géhu J.-M., 2011 - On the opportunity to celebrate the centenary of modern phytosociology in 2010, Plant Biosystems, 145, 4-8.

28. Géhu J.-M. and Rivas-Martínez S., 1981 - Notions fondamentales de phytosociologie, Berichte der Internationalen Symposien der Internationalen Vereinigung für Vegetationskunde, Syntaxonomie, Cramer J., Berlin, 5-33, XVII, 11-45. (in French)

29. Gibson A. H., 1934 - Models of tidal estuaries, Nature, 133, 605-606, https://doi.org/10.1038/133605d0.

30. Gillet F., De Foucault B. and Julve P., 1991 - La phytosociologie synusiale intégrée: objets et concepts, Candollea, 46, 2, 315-340. (in French)

31. Gnanadesikan A., 1999 - A simple predictive model for the structure of the oceanic pycnocline, Science, 283, 5410, 2077-2079.

32. Guilcher A., Andrade B. and Dantec M.-H., 1982 - Diversité morpho-sédimentologique des estuaires du Finistère, Norois, 114 (Avril-Juin), 205-228. (in French)

33. Guinochet M., 1973 - Phytosociologie, Ed. Masson, Paris, 227. (in French)

34. Guo L., van der Wegen M., Jay D. A., Matte P., Wang Z. B., Roelvink D. and He Q., 2015 River-tide dynamics: Exploration of nonstationary and nonlinear tidal behavior in the Yangtze River estuary, Journal of Geophysical Research: Oceans, 120, doi:10.1002/2014JC010491. (in French)

35. Hansen D. V. and Rattray M. Jr., 1966 - New dimensions in estuary classification, Limnology and Oceanography, 11, 319-326.

36. Kestner F. J. T., 1966 - The effects of engineering works on tidal estuaries, in Thorn (ed.), River engineering and water conservation works, Butterworths, London, 226-238.

37. Kragtwijk N. G., Zitman T. J., Stive M. J. F. and Wang Z. B., 2004 - Morphological response of tidal basins to human interventions, Coastal Engineering, 51, 207-221.

38. Lambiase J. J., 1980 - Sediment dynamics in the macrotidal Avon River estuary, Bay of Fundy, Nova Scotia, Canadian Journal of Earth Science, 17, 1628-1641.

39. Lazare J.-J., 2009a - Phytosociologie dynamico-caténale et gestion de la biodiversité, Acta Botanica Gallica, 156, 1, 46-61. (in French)

40. Le Dez M., Sawtschuk J. and Bioret F., 2017a - Les prairies de l'estuaire de la Loire: étude de la dynamique de la végétation de 1982 à 2014, 119 http://mappemonde.mgm.fr/119as2/|1. (in French) 
41. Le Dez M., Sawtschuk J., Bioret F., Le Hir P. and Walther R., 2017b - Anticiper les impacts du changement climatique dans un milieu naturel soumis à de fortes contraintes anthropiques: l'estuaire de la Loire, Norois, 245, 4, 15-28. (in French)

42. Mann K. H. and Lazier J. R. N., 2013 - Dynamics of marine ecosystems, III ed., Blackwell Publishing, Hoboken, USA, 512.

43. Middelburg J. J. and Herman P. M. J., 2007 - Organic matter processing in tidal estuaries, Marine Chemistry, 106, 1-2, 127-147, https://doi.org/10.1016/j.marchem.2006.02.007.

44. Muchiut S., Susperregui N. and Soulier L., 2008 - Valorisation des services rendus par les écosystèmes estuariens et côtiers en regard de l'activité de pêche professionnelle - exemple du littoral Aquitain, 81. (in French)

45. Orton P. M. and Kineke G. C., 2001 - Comparing calculated and observed vertical suspendedsediment distributions from a Hudson River estuary turbidity maximum, Estuarine, Coastal and Shelf Science, 52, 401-410.

46. Owen M. W. and Odd N. V. M., 1972 - A mathematical model of the effect of a tidal barrier on siltation in an estuary, in Gray and Gashius (eds), Tidal power: Proceedings of an International Conference on the utilization of tidal power, (Halifax, NS) Plenum Press, New York-London, 457-485.

47. Pedrotti F., 2013 - Plant and vegetation mapping, Springer, 294.

48. Perales-Valdivia H., Sanay-González R. and Valle-Levinson A., 2018 - Effects of tides, wind and river discharge on the salt intrusion in a microtidal tropical estuary, Regional Studies in Marine Science, 24, 400-410.

49. Petrilli A., 2006 - L’urbanistica di Le Corbusier, Marsilio Ed., Venezia, Italy. 238. (in Italian)

50. Pignatti S., 1995 - Ecologia vegetale, UTET, Torino, Italy 532. (in Italian)

51. Pirola A., 1999 - Elementi di fitosociologia, CLUEB, Bologna, Italy, 156. (in Italian).

52. Pritchard D. W., 1955 - Estuarine circulation patterns, Proceedings of the American Society of Civil Engineers, 81, 717, 1-11.

53. Rivas-Martínez S., 1976 - Sinfitosociologia, una nueva metodologia para el estudio del paisaje vegetal, Anales del Instituto Botánica J. Cavanilles (Anales del Jardin Botánico de Madrid), 33, 179-188. (in Spanish)

54. Sawtschuk J. and Bioret F., 2012 - Analyse diachronique de la dynamique spatiale de la végétation de l'estuaire de la Loire, Photo-interprétation, 48, 3, 15-28. (in French)

55. Schwabe A., 1989 - Vegetation complexes of flowing-water habitats and their importance for the differentiation of landscapes units, Landscape Ecology, 2, 4, 237-253.

56. Sender J., Cianfaglione K. and Kolejko M., 2014 - Evaluation of ecological state of small water reservoirs in the Bystrica River valley, Teka Komisji Ochrony I Kształtowania Środowiska Przyrodniczego, OLPAN, 11, 173-180.

57. Sender J., Maslanko W., Różanska-Boczula M. and Cianfaglione K., 2017 - A new multicriteria method for the ecological assessment of lakes: a case study from the Transboundary Biosphere Reserve "West Polesie", Poland, Journal of Limnology, 76, s1, 60-74, DOI: 10.4081/jlimnol.2017.1639.

58. Shi Z., Lamb H. F. and Collin R. L., 1995 - Geomorphic change of salt marsh tidal creek networks in the Dyfi Estuary, Wales, Marine Geology, 128, 73-8.

59. Strang E. J. and Fernando H. J. S., 2001 - Vertical mixing and transports through a stratified shear layer, Journal of Physical Oceanography, 31, 2026-2048.

60. Theurillat J.-P., 1992a - Ètude symphytocoenologiques dans la région d'Aletsch (Valais, Suisse), Thèse de doctorat en Science, Université de Berne, 398. (in French)

61. Theurillat J.-P., 1992b - L'analyse du paysage végétal en sympphytosociologie: ses niveaux et leurs domaines spatiaux, Bulletin d'Écologie, 23, 1-2, 83-92. (in French) 
62. Thrush S. F., Townsend M., Hewitt J. E., Davies K., Lohrer A. M., Lundquist C. and Cartner K., 2013 - The many uses and values of estuarine ecosystems, in Dymond J. R (ed.), Ecosystem services in New Zealand - conditions and trends, Manaaki Whenua Press, Lincoln, New Zealand, 226-237.

63. Tockner K., Zarfl C. and Robinson C., 2021 - Rivers of Europe, ISBN: 9780081026120, 800.

64. Tüxen R., 1973 - Vorschlag zur Aufnahme von Gesellschaftskomplexen in potentiell natürlichen Vegetationsgebieten, Acta Botanica Academia Hungarica, 19, 379-384. (in German)

65. Tüxen R., 1978 - Assoziationskomplexe (Sigmeten) und ihre praktische Anwendung, Berichte der Internationalen Symposien der Internationalen Vereinigung für Vegetationskunde, 18, Cramer, Vaduz, 1-536. (in German)

66. Tüxen R., 1979 - Sigmeten und Geosigmeten, ihre Ordnung und ihre Bedeutung für Wissenschaft, Naturschutz und Planung, Biogeographica, 16, 79-92. (in German)

67. Ubaldi D., 2012 - Guida allo studio della flora e della vegetazione, CLUEB, Bologna, Italy, 253. (in Italian)

68. Valle-Levinson A., 2010 - Contemporary issues in estuarine physics, Cambridge University Press, 1-11.

69. $\quad$ van Der Maarel E., 1975 - The Braun-Blanquet approach in perspective, Vegetatio, 30, 3, $213-$ 219.

70. Van Proosdij D., Milligan T., Bugden G. and Butler K., 2009 - Tale of two macro tidal estuaries: differential morphodynamic response of the intertidal zone to causeway construction, ICS2009 (Proceedings), Journal of Coastal Research, SI 56, 772-77.

71. Verger F., 1995 - Slikkes et Schorres: milieux et aménagement, Norois, 165, 235-245. (in French)

72. Verger F., 2005 - Marais et estuaires du littoral français, Belin Ed., Paris, France, 335. (in French)

73. Weber H. E., Moravec J. and Theurillat J.-P., 2000 - International Code of Phytosociological Nomenclature, 3rd edition, Journal of Vegetation Science, 1, 739-768.

74. Wells J. T., 1995 - Tide-dominated estuaries and tidal rivers, Chapter 6. In Perillo G. M. E. (ed.), Developments in Sedimentology, Elsevier, 53, 179-205, https://doi.org/10.1016/S00704571(05)80026-3.

75. Woodroffe C. D., 2002 - Coasts: form, process and evolution, Cambridge University Press, New York, 623.

76. $\quad *$ - https://oceanservice.noaa.gov/facts/estuary.html

77. $* *$ - https://inpn.mnhn.fr/actualites/lire/1241/; http://patrinat.mnhn.fr/programmes/22/CarHAB; http://www.trameverteetbleue.fr/outils-methodes/donnees-mobilisables/projet-carhab; http://letg.cnrs.fr/article869.html 